\title{
GAMBARAN PENERAPAN TERAPI PIJAT OKSITOSIN PADA IBU POST PARTUM
}

\author{
Kurniati Devi Purnamasari \\ Prodi D III Kebidanan, Fakultas Ilmu Kesehatan, Universitas Galuh, Indonesia \\ Corresponding Email: kurniatidevip@gmail.com \\ (Diterima 02-05-2020; disetujui 09-05-2020; dipublish 27-05-2020)
}

\begin{abstract}
ABSTRAK
Banyak bukti seputar pemberian Air Susu Ibu (ASI) saat ini tidak mencerminkan pengalaman ibu ketika menyusui, meskipun pengalaman perempuan telah dieksplorasi dalam konteks tertentu. Terapi pijat oksitosin pada ibu dapat membantu dalam peningkatan produksi ASI selama masa nifas khususnya dalam mendukung pemberian ASI ekslusif pada bayi usia 0-6 bulan pertama kelahiran. Penerapan pijat oksitosin dapat mempengaruhi faktor psikologis sehingga meningkatkan relaksasi dan tingkat kenyamanan ibu, sehingga memicu produksi hormon oksitosin dan mempengaruhi pengeluaran ASI. Efek pijat oksitosin adalah sel kelenjar payudara mensekresi ASI sehingga bayi mendapatkan ASI sesuai dengan kebutuhan dan berat badan bayi bertambah. Penelitian ini bertujuan mengetahui gambaran penerapan tindakan pijat oksitosin pada ibu post partum. Jenis Penelitian kualitatif dengan metode deskriptif serta pengambilan sampel dengan total sampling pada ibu post partum. Pengambilan data dengan wawancara mendalam di dapatkan hasil antara lain gambaran pengetahuan tentang pijat oksitosin masih sangat kurang, berfokus pada tujuannya untuk pengeluaran ASI, gambaran sikap ibu tentang penerapan pijat oksitosin.
\end{abstract}

Kata kunci: ASI, post partum, pijat oksitosin

\begin{abstract}
Much of the evidence surrounding breastfeeding does not currently reflect the mother's experience when breastfeeding, although women's experiences have been explored in certain contexts oxytocin massage therapy in the mother can help in increasing milk production during the puerperium especially in supporting exclusive breastfeeding in infants aged The first $0-6$ months of birth. The application of oxytocin massage can influence psychological factors, thereby increasing the relaxation and comfort level of the mother, thereby triggering the production of the hormone oxytocin and affecting the expenditure of breast milk. The effect of oxytocin massage is breast glandular cells secrete milk so that the baby gets milk according to the needs and the baby's weight increases. This study aims to describe the application of oxytocin massage in post partum mothers. Type of qualitative research with descriptive methods and sampling with total sampling in post partum mothers. Retrieval of data with in-depth interviews was obtained, among others, the description of knowledge about oxytocin massage was still lacking, focusing on its purpose for breastfeeding, description of maternal attitudes about applying oxytocin massage.
\end{abstract}

Keywords: EBF, post partum, oxytocin massage

\section{PENDAHULUAN}

Air Susu Ibu (ASI) merupakan

makanan paling sempurna bagi bayi

terutama di bulan usia 0-6 kehidupannya

(Bakara \& Susanti, 2019). Cakupan

pemberian Air Susu Ibu (ASI) ekslusif di
Indonesia masih rendah. Berdasarkan data Susenas (Survei Sosial Ekonomi Nasional) tahun 2010, baru ada 33,6 persen bayi umur 0-6 bulan yang mendapatkan ASI eksklusif, artinya masih ada sekitar $2 / 3$ bayi di Indonesia yang kurang mendapatkan ASI 


\section{Kurniati Devi Purnamasari}

(Indonesia, 2011). Hal ini diperkuat dengan data Riset Kesehatan Dasar (Riskesdas) Tahun 2010 yang menyebutkan bahwa hanya 15,3 persen bayi umur kurang dari 6 bulan yang mendapat ASI eksklusif (Kesehatan, 2010).

Secara fisiologis, peranan ASI sangat berpengaruh dalam pemenuhan nutrisi dan kekebalan tubuh bagi bayi, dan sebagai pilar utama dalam tumbuh kembang bayi di tingkat kognitif, perilaku dan motorik (Horta et al., 2018). Manfaat menyusui bagi ibu dapat meningkatkan kadar oksitosin yang dapat membantu dalam proses involusi uterus selama masa nifas (Krol et al., 2018). Pijatan oksitosin telah menjadi terapi yang dapat menurunkan laju Adenocorticotropic Hormon (ACTH) dan yang mungkin membantu sekresi hormon dan prolaktin guna meningkatkan produksi ASI (Winter \& Jurek, 2019). ASI memiliki tingkat perkembangan kognitif yang lebih tinggi dibandingkan bayi yang diberilan susu formula. Salah satu penjelasan dari hasil penelitian tersebut adalah $60 \%$ dari otak bayi tersusun dari lemak, terutama DHA dan asam arachidonat (AA), dan ASI mengandung asam lemak tak jenuh rantai panjang (LCPUFAs) seperti DHA dan AA yang merupakan zat gizi ideal untuk pertumbuhan otak bayi yang belum matang (Fikawati, 2015).

\section{METODE PENELITIAN}

Jenis penelitian yang digunakan adalah penelitian kualitatif. Rancangan penelitian ini menggunakan metode deskriptif Analitik. Tujuan utama penelitian ini adalah menggambarkan penerapan tindakan pijat oksitosin pada ibu post partum. Pengambilan sumber data penelitian ini menggunakan tehnik total sampling. Subjek penelitian ini sejumlah 2 orang Ibu Post Partum dengan riwayat persalinan normal. Penelitian penerapan tindakan pijat oksitosin pada ibu post partum dilaksanakan di Wilayah Kerja Puskesmas Cipaku.

Pengumpulan data penelitian dengan wawancara mendalam. Alat penunjang penelitian antara lain pedoman Wawancara Mendalam (Indept Interview), Log book dan Alat tulis. Pengolahan data dengan mentranskripsikan seluruh data secara utuh berdasarkan topik, dikembangkan ke bentuk bahasa yang lebih baku, secara naratif dan direduksi dalam rangkuman.

Teknik pijat oksitosin adalah tindakan pijat pada bagian tulang belakang (vertebra) mulai dari serviks 7 ke kosta hingga 5-6 hingga skapula yang akan mempercepat kerja saraf parasimpatis untuk mengirimkan perintah ke bagian belakang otak untuk menghasilkan oksitosin

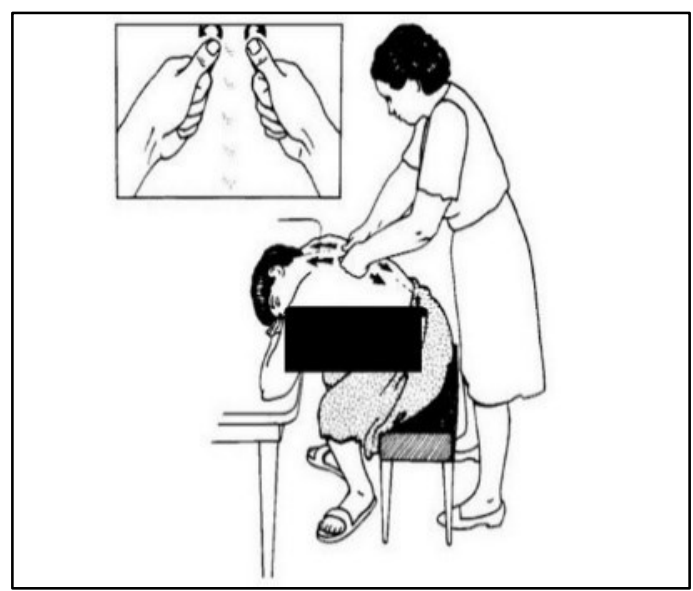

Gambar 1

Referensi Teknik Pijat Oksitosin 


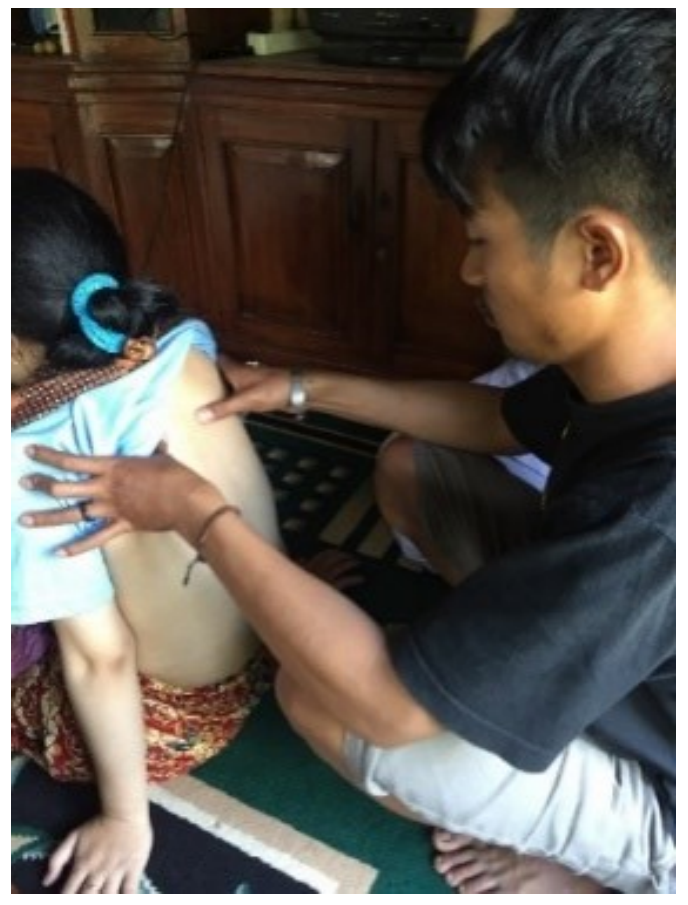

Gambar 2

Teknik Pijat Oksitosin

\section{HASIL DAN PEMBAHASAN}

Penelitian deskriptif kualitatif tentang gambaran penerapan pijat oksitosin pada ibu post partum di Rumah Sakit Islam Sunan Kudus di laksanakan dalam 2 tahap yaitu indepth interview dengan responden dan menyimpulkan hasil indepth interview. Karakteristik subjek informan penelitian yang digunakan dalam penelitian ini sebagai berikut:

Tabel 1

Karakteristik Responden untuk indepth interview

\begin{tabular}{ccccc}
$\begin{array}{c}\text { Respon } \\
\text { den }\end{array}$ & $\begin{array}{c}\text { Um } \\
\text { ur }\end{array}$ & $\begin{array}{c}\text { Pendidik } \\
\text { an }\end{array}$ & $\begin{array}{c}\text { Pekerja } \\
\text { an }\end{array}$ & $\begin{array}{c}\text { Gravi } \\
\text { da }\end{array}$ \\
\hline $\mathrm{p}-1$ & 18 & SMA & IRT & 1 \\
p-2 & 26 & SMA & IRT & 2
\end{tabular}

\section{Gambaran Pengetahuan ibu post partum tentang Pijat Oksitosin}

Pengetahuan subyek penelitian tentang pijat oksitosin sangat kurang, semua subjek belum tahu tentang definisi pijat oksitosin. Berikut ini adalah gambaran pengetahuan tentang pijat oksitosin. Semua subjek penelitian tidak mengetahui definisi dengan benar tentang pijat oksitosin. Definisi pijat oksitosin menurut subyek adalah Pijat relaksasi yang dilakukan di belakang tengkuk sampai bawah untuk pengeluaran ASI. Di bawah ini adalah kutipan hasil wawancara mendalam.

$$
\begin{aligned}
& \text { Kotak } 1 \\
& \text { “...Tidak tahu... ” R1 } \\
& \text { “...Belum pernah melakukan....” R2 }
\end{aligned}
$$

Subjek penelitian belum mengetahui tujuan pijat oksitosin dengan benar. Tujuan pijat oksitosin menurut subyek adalah Merangsang dan mempercepat pengeluaran ASI. Di bawah ini adalah kutipan hasil wawancara mendalam

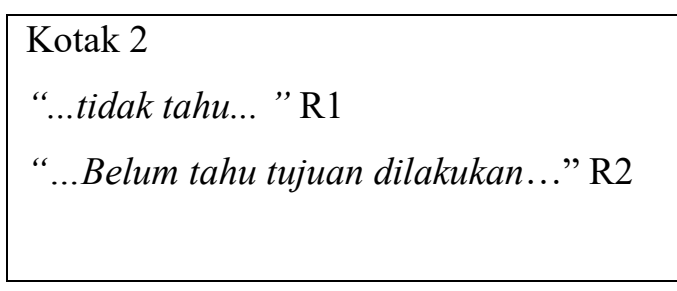

Semua subjek penelitian tidak mengetahui cara melakukan pijat oksitosin dengan benar. Cara melakukan pijat oksitosin menurut subyek adalah Memijat dari tulang leher pertama sampai tulang belikat, bisa memakai minyak atau tidak, dengan posisi sambil duduk atau sambil tiduran. Di bawah ini adalah kutipan hasil wawancara mendalam.

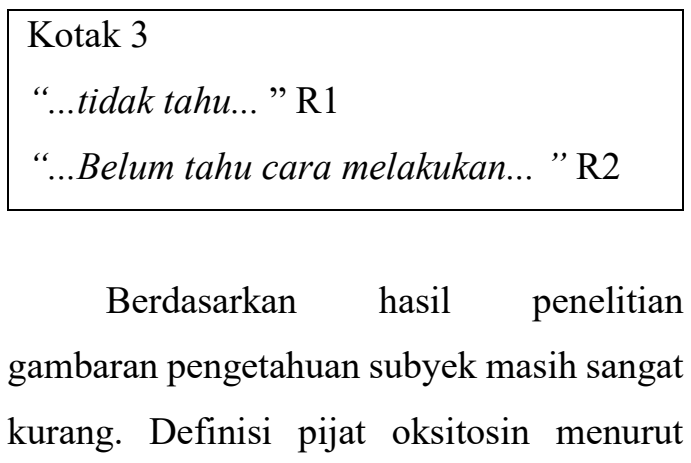


subyek adalah Pijat relaksasi yang dilakukan di belakang tengkuk sampai bawah untuk pengeluaran ASI. Tujuan pijat oksitosin menurut subyek adalah merangsang dan mempercepat pengeluaran. Cara melakukan pijat oksitosin menurut subyek adalah Memijat dari tulang leher pertama sampai tulang belikat, bisa memakai minyak atau tidak, dengan posisi sambil duduk atau sambil tiduran. Pengetahuan yang diperoleh subyek penelitian berasal dari penjelasan orang yang mempunyai pengetahuan tentang pijat oksitosin. Proses pengetahuan ini sesuai dengan teori domain perilaku bahwa pengetahuan dapat diperoleh dari pengalaman sendiri maupun dari pengalaman orang lain. Pijat oksitosin adalah pemijatan pada punggung dan tengkuk ibu untuk merangsang keluarnya hormon oksitosin

Hormon oksitosin adalah hormon yang dihasilkan oleh kelenjar hipofisa posterior. Hormon ini bertanggung jawab untuk mengalirkan ASI yang telah di produksi prolaktin kesaluran laktiferus dan sampai kemulut bayi melalui isapannya. Pijat Oksitosin bertujuan untuk merangsang pengeluaran hormon oksitosin supaya pengeluaran ASI pada ibu post partum menjadi lancar Pijat Oksitosin bertujuan untuk merangsang pengeluaran hormon oksitosin supaya pengeluaran ASI pada ibu post partum menjadi lancar.

Langkah pijatan oksitosin adalah ibu duduk, bersandar kedepan, lipat lengan diatas meja di depanya dan letakkan kepalanya di atas lenganya dan payudara tergantung lepas tanpa pakaian, selanjutnya perawat memijat sepanjang sisi tulang belakang ibu dengan menggunakan dua kepalan tangan, dengan ibu jari menunjuk ke depan dan menekan kuatkuat kedua sisi tulang belakang membentuk gerakangerakan melingkar kecilkecil dengan kedua ibu jarinya, pada saat bersamaan, pijat ke arah bawah pada kedua sisi tulang belakang, dari leher kearah tulang belikat, selanjutnya lakukan pemijatan hingga batas tali bra, lakukan pemijatan selama 2 atau 3 menit.

\section{Gambaran Sikap subyek penelitian dalam penerapan tindakan pijat oksitosin} Sikap subyek penelitian (tenaga keperawatan) dalam melaksanakan pijat oksitosin melaksanakan dengan senang hati sesuai teori yang pernah diajarkan, agar ASI ibu segera keluar. Berikut ini adalah kutipan sikap subyek penelitian:

Kotak 4
“...Responden mengatakan merasa
senang dan nyaman... ” $\mathrm{R} 1$
“...Responden mengatakan posisi sambil
duduk lebih nyaman dibandingkan sambil
tiduran...” $\mathrm{R} 2$

Berdasarkan hasil penelitian sikap subyek penelitian sangat mendukung adanya penerapan tindakan pijat oksitosin, namun untuk kewajiban melaksanakan memerlukan peraturan resmi dari rumah sakit. Respon positif sikap mendukung subyek penelitian menunjukkan tenaga keperawatan menerima ide dalam pelaksanaan tindakan pijat oksitosin. Sikap merupakan reaksi atau respon emosional seseorang terhadap stimulus atau objek diluarnya, respon 
emosional ini lebih bersifat penilaian dan dapat dilanjutkan dengan kecenderungan untuk melakukan atau tidak melakukan sesuatu stimulus kegiatan.

\section{Gambaran Praktik penerapan tindakan pijat oksitosin}

Semua subjek penelitian belum melaksanakan penerapan pijat oksitosin, namun secara perorangan subyek penelitian melakukan tindakan pijat oksitosin berdasarkan informasi dari mahasiswa praktik, pembimbing akademik yang bimbingan di komunitas dan peneliti yang pernah melakukan penelitian tentang tindakan pijat oksitosin. Berikut ini adalah kutipannya.

Kotak 5
“...Dilakukan namun jarang karena
terkadanglupa....” 1
“...Dilakukan oleh suami setiap hari
pada pagi hari...” 2

Bidan mengevaluasi keberhasilan tindakan pijat oksitosin yang dilakukan pada pasien post partum dan hasilnya pasien yang dilakukan pijat oksitosin lebih cepat keluar ASI nya di banding ibu post partum yang tidak di lakukan pijat oksitosin

\section{SIMPULAN}

Gambaran pengetahuan ibu post partum tentang pijat oksitosin masih sangat kurang, sedangkan tenaga keperawatan hanya berfokus pada tujuannya untuk pengeluaran ASI

Gambaran sikap tenaga keperawatan tentang penerapan pijat oksitosin sangat mendukung dan akan segera di proses untuk pengajuan kebijakan dalam penerapan tindakan pijat oksitosin pada ibu post partum Gambaran praktik penerapan pijat oksitosin pada ibu post partum masih sangat kurang oleh tenaga keperawatan di ruang post partum dan SOP tentang pijat oksitosin sebagai acuan masih belum ada.

\section{DAFTAR PUSTAKA}

1. Agus, R. (2011). Pengolahan dan Analisis Data Kesehatan. Yogyakarta: Nuha Medika

2. Arikunto,S. (2010). Prosedur Penelitian Suatu Pendekatan Praktik. Jakarta: Rineka Cipta.

3. Asrinah et al. (2010). Asuhan Kebidanan Masa Kehamilan. Yogyakarta: Graha Ilmu.

4. Berlianty et al. (2013). Analisis Loyalitas Pasien Berdasarkan Kualitas Pelayanan di Instalasi Rawat Inap RS. Bhayangkara Mappa Oudang Kota Makassar Tahun 2013. repository.unhas.ac.id. Di unduh pada tanggal 10 Pebruari 2015

5. Budiman. (2011). Penelitian Kesehatan. Bandung: PT. Refika Aditama

6. Dalimunthe et al. (2010). Analisis Persepsi Pasien Partikulir Tentang Kualitas Pelayanan Terhadap Tingkat Loyalitas di Ruang Rawat Inap RS Islam Malahayati Medan Tahun 2007. repository.usu.ac.id. Di unduh pada tanggal 10 Pebruari 2015.

7. Dinkes. (2010). Pedoman Pelayanan Antenatal Terpadu. Jakarta:Kementerian Kesehatan 
Kurniati Devi Purnamasari

8. Hani, et al. (2010). Asuhan Kebidanan pada Kehamilan Fisiologis. Jakarta: Salemba Medika.

9. Hidayat, A.A. (2010). Metode Penelitian Kebidanan dan Teknik Analisis Data. Jakarta: Rineka Cipta

10.Depkes RI. (2007). Pelatihan Konseling Menyusui. Jakarta : Depkes RI 